\title{
Tailor-made fuels for future engine concepts
}

\author{
Fabian Hoppe', Benedikt Heuser', Matthias Thewes², Florian Kremer', \\ Stefan Pischinger', Manuel Dahmen ${ }^{3}$, Manuel Hechinger ${ }^{3}$ and \\ Wolfgang Marquardt ${ }^{3}$
}

\begin{abstract}
Increasing carbon dioxide accumulation in earth's atmosphere and the depletion of fossil resources pose huge challenges for our society and, in particular, for all stakeholders in the transportation sector. The Cluster of Excellence 'Tailor-Made Fuels from Biomass' at RWTH Aachen University establishes innovative and sustainable processes for the conversion of whole plants into molecularly well-defined fuels exhibiting tailored properties for low-temperature combustion engine processes, enabling high efficiency and low pollutant emissions. The concept of fuel design, that is, considering fuel's molecular structure to be a design degree of freedom, aims for the simultaneous optimisation of fuel production and combustion systems. In the present contribution, three examples of tailor-made biofuels are presented. For spark ignition engines, both 2-methylfuran and 2-butanone show increased knock resistance compared to RON95 gasoline, thus enabling a higher compression ratio and an efficiency gain of up to $20 \%$ at full-load operation. Moreover, both fuels comprise a good mixture formation superior to the one of ethanol, especially under difficult boundary conditions. For compression ignition engines, I-octanol enables a remarkable reduction in engine-out soot emissions compared to standard diesel fuel due to the high oxygen content and lower reactivity. This advantage is achieved without sacrificing the high indicated efficiency and low $\mathrm{NO}_{x}$ emissions.
\end{abstract}

\section{Keywords}

Biofuels, spark ignition engines, compression ignition engines, 2-butanone (methyl ethyl ketone), 2-methylfuran, ethanol, I-octanol

Date received: 12 May 2015; accepted: 6 August 2015

\section{Introduction}

The energy supply situation for individual mobility and automotive cargo transportation is expected to change drastically, primarily due to the need to reduce carbon dioxide emissions resulting from the combustion of fossil fuels. While internal combustion engines running on gasoline and diesel dominate the market currently, an increase in the diversification of fuels and powertrains is projected for the transportation sector. ${ }^{1}$ Liquid fuels based on renewable raw materials (biofuels) hold the promise of closing the carbon cycle. They can be stored, handled and moved around easily and exhibit a high energy density. Moreover, worldwide infrastructure for liquid fuel distribution exists, and advanced internal combustion engines combine high efficiency and low emissions of pollutants.

The shift from fossil fuels to renewable feedstock offers the opportunity to redesign the entire value chain and to fully unlock the potential of future engine concepts. To this end, the molecular structure of fuel is considered a design degree of freedom in the simultaneous optimisation of engine performance and sustainability of production. From the combustion point of view, the ideal properties of a biofuel will probably differ considerably from those of current conventional fuels and first-generation biofuels.

One motivation for the Cluster of Excellence (CoE) 'Tailor-Made Fuels from Biomass' (TMFB) at RWTH Aachen University is to unravel the complex

\footnotetext{
IInstitute for Combustion Engines (VKA), RWTH Aachen University, Aachen, Germany

${ }^{2} \mathrm{FEV} \mathrm{GmbH}$, Aachen, Germany

${ }^{3}$ Process Systems Engineering, Aachener Verfahrenstechnik, RWTH

Aachen University, Aachen, Germany

\section{Corresponding author:}

Fabian Hoppe, Institute for Combustion Engines (VKA), RWTH Aachen University, Forckenbeckstr. 4, 52074 Aachen, Germany.

Email: hoppe@vka.rwth-aachen.de
} 


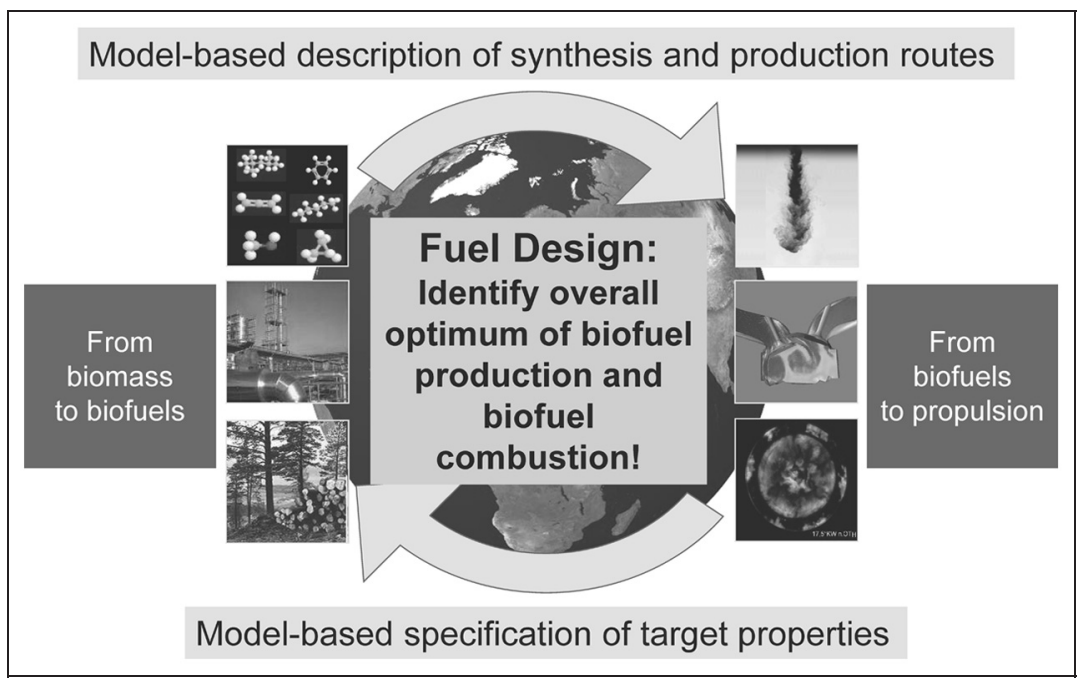

Figure I. Design of tailored biofuels exhibiting superior engine-relevant properties and sustainable production pathways.

relationships between fuel molecular structure and engine performance. The present contribution will give a brief overview of the fuel design process, as applied within TMFB, followed by examples of tailor-made fuels for spark ignition (SI) and compression ignition (CI) engines. The focus of this publication is to investigate the influence of pure fuel molecules on combustion behaviour by avoiding cross influences of the base fuel (gasoline or diesel). Investigations on blends with identified biofuels will be conducted in the next section.

\section{Fuel design}

The vision of TMFB fuel design is the joint modelbased description and optimisation of liquid fuel production in bio-refineries and energy conversion in internal combustion engines (cf. Figure 1). ${ }^{2,3}$ Selective bioand chemo-catalytic process steps aim for an energyand carbon-efficient conversion of lignocellulosic biomass into molecularly well-defined fuel compounds. Generally, preservation of nature's synthetic power to the extent possible is envisaged to minimise the number of process steps in the transformation process (cf. Figure 2). ${ }^{2,4}$ Because the biomass feedstock is generally rich in oxygen, the focus lies on medium-sized oxygenated hydrocarbons constituting promising fuel compounds. Oxygenates have been found to significantly reduce $\mathrm{CI}$ engine-out soot emissions ${ }^{7}$ and are currently routinely blended into gasoline to increase its octane rating.

Examples for the selective catalytic transformation of bio-derived platform molecules into fuel candidates have been previously reported by TMFB researchers. ${ }^{8}$ Di-n-butylether (DnBE) and 2-methyltetrahydrofuran (2-MTHF) have been studied extensively in the CI engine. Both oxygenated fuels burn almost soot- and $\mathrm{NO}_{\mathrm{X}}$-free in an optimised engine configuration. ${ }^{7}$ More recently, TMFB researchers discovered a bio-based synthesis route towards $\mathrm{C} 8$ and $\mathrm{C} 9$ alcohols. ${ }^{9}$ This has

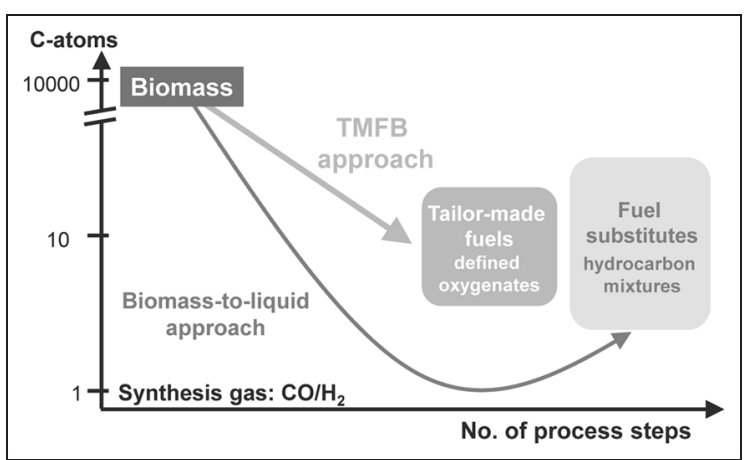

Figure 2. Direct refunctionalisation of biomass monomers to preserve the synthesis power of nature, in contrast to the biomass-to-liquid (BtL) approach.

triggered the investigation of 1-octanol as a prototype for a long-chained alcoholic biofuel in diesel combustion due to its promising derived cetane number (DCN) of 33.1 .

The TMFB fuel design process describes a holistic framework evolving around different tools and methods for computational and fundamental experimental identification and the investigation of biofuel candidates. Hechinger ${ }^{10}$ has identified 2-butanone as a promising advanced biofuel for SI engines by means of a computational approach to fuel design. This compound serves as an example to illustrate the still evolving TMFB fuel design framework (cf. Figure 3). ${ }^{10}$ Starting from a set of desired fuel properties, an exhaustive computational search of the molecular space comprising all mathematically feasible $\mathrm{C}_{\mathrm{X}} \mathrm{H}_{\mathrm{Y}} \mathrm{O}_{\mathrm{Z}}$ structures containing 1-8 carbon atoms was performed. The generation of molecular graphs was restricted only by the valence rules. Consequently, $\sim 168.8$ million structures had to be sequentially reduced to identify a small set of most promising molecular entities for further investigation. A first reduction could be achieved by excluding infeasible substructures and molecular patterns, which were 


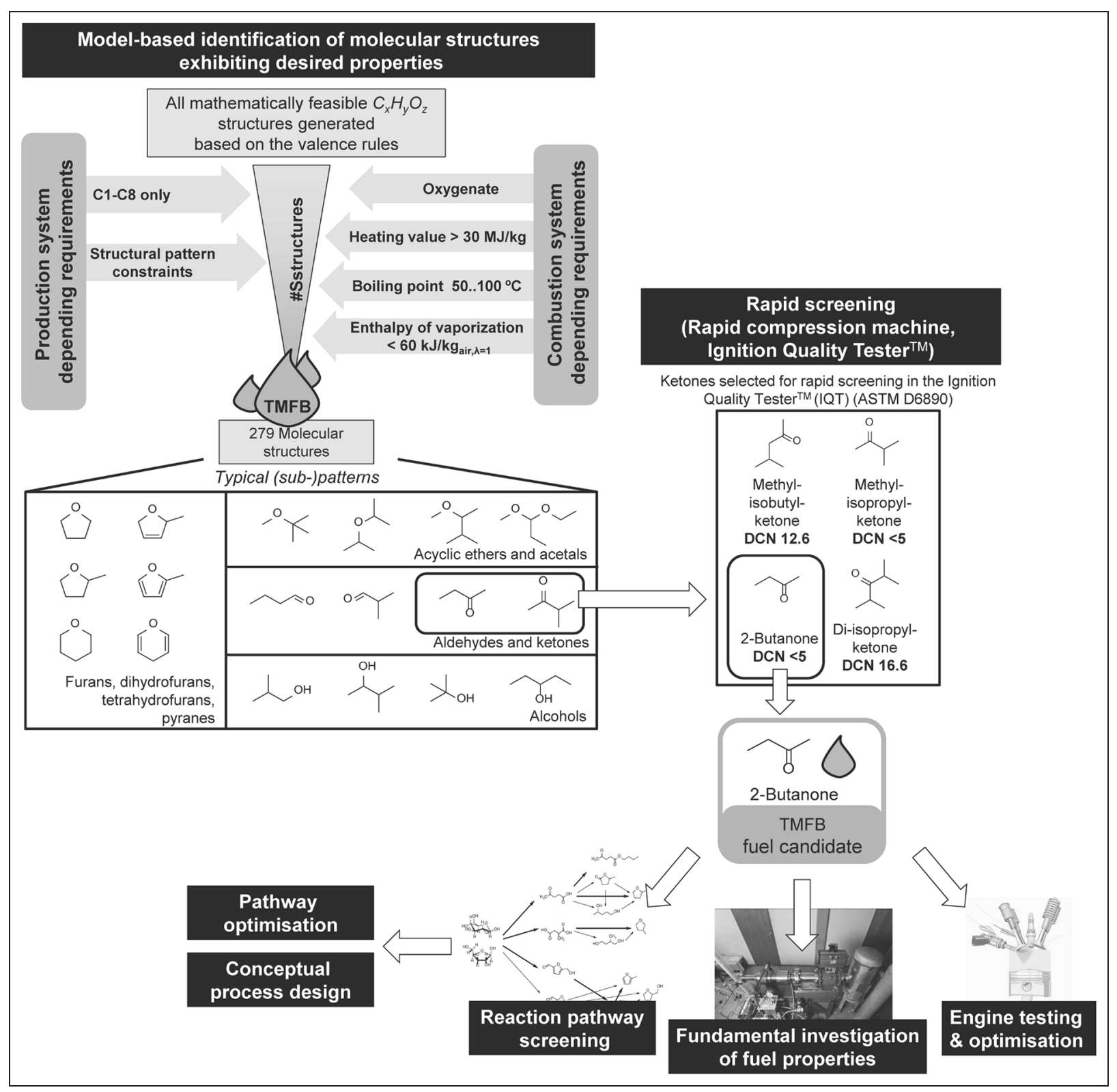

Figure 3. Example of the TMFB fuel design process: identification of 2-butanone as a prototype for a ketonic biofuel.

difficult to obtain from the selective chemo-catalytic transformation of biomass monomers. ${ }^{10}$ Subsequently, the remaining $\sim 12.4$ million molecular structures were screened in silico for oxygenated biofuel candidates with the help of tailored quantitative structureproperty relationships (QSPRs; cf. Figure 3). ${ }^{10,11}$ The final 279 candidates were categorised into acyclic ethers, ketones, aldehydes, alcohols and furan derivatives (cf. Figure 3), where unsaturated and branched molecules constitute the majority. ${ }^{10}$ Due to favourable boiling characteristics, ketones were chosen for further investigation, despite the limited experience regarding their auto-ignition quality and knock resistance. Rapid screening in an Ignition Quality Tester ${ }^{\mathrm{TM}}$ (ASTM D6890) revealed remarkably low auto-ignition capabilities for 2-butanone $(\mathrm{DCN}<5)$, methyl isobutyl ketone (DCN 12.6), diisopropyl ketone (DCN 16.6) and methyl isopropyl ketone (DCN $<5$ ). Subsequent octane number determination yielded exceptionally high research octane number (RON 117) and motor octane number (MON 107) for 2-butanone.

Model-based fuel identification and rapid experimental screening were augmented with a variety of experimental facilities used to unravel the relationships between the molecular structure and key fuel properties such as auto-ignition and lubricity (cf. Figure 3). Reaction network flux analysis (RNFA), an optimisation-based methodology for the rapid evaluation of competing reaction pathways, allowed for comparing the economic and ecological potentials of the investigated molecules. ${ }^{12}$ The most promising biofuel candidates were forwarded to engine experimentation and optimisation, as well as conceptual process design and life-cycle assessment, to acquire detailed 
Table I. Properties of investigated fuels for SI operation. ${ }^{14,17-22}$

\begin{tabular}{|c|c|c|c|c|c|c|}
\hline & & $\begin{array}{l}\text { RON95 E5 } \\
\text { gasoline EN228 }\end{array}$ & $\begin{array}{l}\text { RON95 EI0 } \\
\text { gasoline EN51626-I }\end{array}$ & Ethanol & 2-Methylfuran & 2-Butanone \\
\hline Sum formula & & Various & Various & $\mathrm{C}_{2} \mathrm{H}_{6} \mathrm{O}$ & $\mathrm{C}_{5} \mathrm{H}_{6} \mathrm{O}$ & $\mathrm{C}_{4} \mathrm{H}_{8} \mathrm{O}$ \\
\hline Carbon mass fraction & $\%$ & 84.47 & 83.48 & 52.14 & 73.15 & 66.63 \\
\hline Hydrogen mass fraction & $\%$ & 13.27 & 13.24 & 13.13 & 7.37 & 11.18 \\
\hline Oxygen mass fraction & $\%$ & 2.26 & 3.28 & 34.73 & 19.49 & 22.19 \\
\hline Density $\left(25^{\circ} \mathrm{C}\right)$ & $\mathrm{kg} / \mathrm{m}^{3}$ & 737 & 741 & 787 & 907.5 & 799 \\
\hline Boiling temperature & ${ }^{\circ} \mathrm{C}$ & $41.5-173.5$ & $35.8-190.4$ & 78 & 64 & 80 \\
\hline Vapour pressure $\left(20^{\circ} \mathrm{C}\right)$ & $\mathrm{kPa}$ & - & - & 5.8 & 13.9 & 10.8 \\
\hline Specific enthalpy of vaporisation & $\mathrm{kJ} / \mathrm{kg}_{\text {air }, \lambda=1}$ & $\sim 28$ & - & 101.6 & 35.52 & 46.10 \\
\hline Stoichiometric air requirement/I & I oant & 14.14 & 13.97 & 8.98 & 10.08 & 10.52 \\
\hline Lower heating value & $\mathrm{MJ} / \mathrm{kg}$ & 42.13 & 41.56 & 26.84 & 30.37 & 31.45 \\
\hline Lower heating value & $\mathrm{MJ} / \mathrm{L}^{\circ}$ & 31.05 & 30.78 & 21.09 & 27.63 & 25.16 \\
\hline Research octane number & 1 & 96.3 & 96.9 & 109 & 101.7 & 117 \\
\hline Motor octane number & I & 85.0 & 86.4 & 89.7 & 82.4 & 107 \\
\hline Purity & $\%$ & - & - & $>99.0$ & $>99.8$ & $>99.9$ \\
\hline
\end{tabular}

information on the performance of combustion and production systems.

\section{TMFB for highly boosted SI engines}

2-Methylfuran and 2-butanone were investigated as pure-compound biofuels in a highly boosted SI engine. Ethanol is known as an excellent biofuel for gasoline engines, especially at high engine loads, due to its high knock resistance and high heat of vaporisation. These characteristics enable high efficiency improvements compared to RON95 gasoline fuel. ${ }^{13-16}$ Therefore, ethanol is defined as the benchmark biofuel for SI engines. As a second benchmark, RON95 (EN228, EN51626-1) gasoline was chosen to represent today's most commonly used conventional fuel for SI engines in the European market. Table 1 summarises the most relevant properties of the investigated fuels. Compared to conventional gasoline, the oxygen mass fraction of the alternative fuels corresponds to a reduction of the mass-specific heating value by $36 \%$ for ethanol, $28 \%$ for 2-methylfuran and $25 \%$ for 2-butanone. For the volume-specific heating value, this trend between the three biofuels is slightly changed, as the reduction of the oxygen content is accompanied by an increase in the density. However, the density of conventional gasoline is lower than that of the biofuels. This results in a reduction of the volume-specific heating value for ethanol by $32 \%$, for 2 -methylfuran by $11 \%$ and for 2 -butanone by $18 \%$ compared to EN228 gasoline. Due to the high oxygen content, the RON and MON of all three biofuels were determined according to DIN51756-7. 2Butanone exhibits the highest RON of all investigated fuels (cf. Table 1). The octane rating of 2-methylfuran is lower than the RON of the other two investigated biofuels. However, it is still five units higher than the RON of conventional gasoline. The high enthalpy of vaporisation of ethanol leads to a charge cooling effect, which is beneficial at high engine loads, thereby reducing the knock tendency in a direct injection engine even further than that depicted by the RON. However, drawbacks arise from the high enthalpy of vaporisation regarding engine start-ability at low ambient temperatures. In combination with low vapour pressure and increased fuel demand, the high charge cooling results in a deterioration of mixture formation due to the low stoichiometric air requirement. ${ }^{13}$ In contrast to ethanol, 2-methylfuran and 2-butanone exhibit latent enthalpies of vaporisations closer to that of gasoline and higher vapour pressures. ${ }^{13,14}$ Consequently, better mixture formation, especially under difficult conditions such as cold starts, is expected for these fuels.

In addition to the enthalpy of vaporisation, the boiling temperature is important for the operation of SI engines. In previous investigations presented by Thewes et al. ${ }^{15}$ the requirement of a boiling temperature of $<100^{\circ} \mathrm{C}$ was stated to enable degassing of fuel from the lube-oil in the oil pan once the engine oil has reached its typical operating temperature of $90{ }^{\circ} \mathrm{C}-$ $100^{\circ} \mathrm{C}$. This criterion is fulfilled for all three investigated biofuels.

\section{Experimental set-up and test conditions}

The experimental testing was conducted on a homogeneously operated, direct injection, SI single-cylinder research engine, known from previous publications. ${ }^{15,23}$ Because both ketones and furans are known for their solvent characteristics, investigations on different seal materials were conducted. $^{24}$ These investigations revealed increased swelling in the case of ethylene propylene diene monomer (EPDM) rubber, fluoroelastomer (FKM) and nitrile butadiene rubber (NBR) for both 2-butanone and 2-methylfuran. Thus, polytetrafluoroethylene (PTFE) or perfluoro-elastomer (FFKM) sealing was used instead in the fuel supply system because no swelling was observed in combination with both fuels. 
Table 2. Hardware specifications of SI single-cylinder engine.

\begin{tabular}{lll}
\hline Bore & $\mathrm{mm}$ & 75 \\
Stroke & $\mathrm{mm}$ & 82.5 \\
Stroke-bore ratio & $\mathrm{I}$ & $\mathrm{I} . \mathrm{I}$ \\
Displacement & $\mathrm{cm}^{3}$ & 364 \\
Number of valves & $\mathrm{I}$ & 4 \\
Integral tumble ratio & $\mathrm{MPa}$ & 3.68 \\
Maximum absolute & $\mathrm{MPa}$ & 0.35 \\
boost pressure & & 8.5 and 13.5 \\
Compression ratios $\left(\mathrm{r}_{\mathrm{C}}\right)$ & $\mathrm{I}$ & 4 \\
Exhaust valve closing $(\mathrm{I} \mathrm{mm})$ & ${ }^{\circ} \mathrm{CA}$ BTDC & 4 \\
Intake valve opening $(\mathrm{I} \mathrm{mm})$ & ${ }^{\circ} \mathrm{CA}$ ATDC & 10 \\
Maximum peak firing pressure & $\mathrm{MPa}$ & 17 \\
Fuel pressure & $\mathrm{MPa}$ & 20 \\
Fuel injector & $\mathrm{I}$. A-nozzle piezo \\
& 2. Six-hole solenoid \\
\hline
\end{tabular}

CA: crank angle; BTDC: before top dead centre; ATDC: after top dead centre.

The engine features high peak pressure capability, external boosting up to $0.35 \mathrm{MPa}$ and a realisation of variable compression ratios by different piston designs. In Table 2, the technical data of the test engine are summarised. A high tumble configuration with an integrated tumble number of 3.68 and symmetrical port geometry was chosen. The spark plug and injector were placed in a central cross position, with the injector installed between the intake valves and the spark plug between the exhaust valves. The injector has an inclination of $6^{\circ}$ and the spark plug of $11.5^{\circ}$.

Two different injectors were used:

1. An outward-opening injector with a nominal spray cone angle of $90^{\circ} \pm 3^{\circ}$ and a maximum needle lift of $\sim 30 \mu \mathrm{m}$, which is directly induced by a piezo stack;

2. A six-hole solenoid actuated injector with an optimised spray pattern with a focus on low liner penetration.

For the thermodynamic measurements, the cylinder pressure was measured with two Kistler A6043 A100 pressure transducers flush-mounted in the combustion chamber roof between each intake and exhaust valve seat ring. Sampling was performed via Kistler 5011 charge amplifiers and a FEV combustion analysis system (FEVIS) at a resolution of $0.1^{\circ}$ crank angle (CA). Dynamic intake and exhaust gas pressures were measured with Kistler 4045 A5 pressure transducers and sampled at a resolution of $1^{\circ} \mathrm{CA}$. In total, 200 consecutive cycles were measured. Measurements of static pressures and temperatures were performed with conventional pressure transducers and thermocouples during an averaging interval of $30 \mathrm{~s}$. Oil and water conditioning systems allowed for steady-state operations. The intake air was conditioned to $25^{\circ} \mathrm{C}$ downstream of the electronically controlled throttle flap. The pressure upstream of the throttle flap and in the exhaust manifold was controlled to $101.3 \mathrm{kPa}$ during throttled operation. For charged operation, the pressure in the exhaust system was set equal to the pressure in the intake manifold. The engine was coupled to an eddycurrent brake and an electric dynamometer to maintain the desired engine speed with an accuracy of $\pm 11 / \mathrm{min}$, regardless of the engine load. For the results presented in Figure 4, the intake air mass flow was measured with a hot-film air mass meter. Fuel consumption was calculated via the air mass flow. The relative air/fuel ratio (AFR; $\lambda$ ) of the exhaust gas was derived according to the formula of Spindt. ${ }^{25}$ For the results presented in Figures 5 and 6, the intake air mass flow was measured with an ultrasonic air mass meter, whereas the fuel consumption was measured via Coriolis-type mass flow sensors. The exhaust measurement used was identical to the one described in Thewes et al. ${ }^{14}$ The gaseous exhaust gas composition was determined from a partial mass flow of exhaust gases, which was sampled $60 \mathrm{~cm}$ downstream of the cylinder head flange. The exhaust gas sample was fed to the following emission analysers via a transfer line heated to $193^{\circ} \mathrm{C}$ :

- HC: flame ionisation detector (Rosemount NGA 2000);

- $\mathrm{O}_{2}$ : paramagnetic oxygen analyser (Rosemount NGA 2000);

- CO: infrared gas analyser (Rosemount NGA 2000);

- $\mathrm{CO}_{2}$ : infrared gas analyser (Rosemount NGA 2000);

- $\mathrm{NO}_{\mathrm{X}}$ : chemiluminescence analyser (Eco Physics 700 EL ht).

Particle emissions were measured downstream of the exhaust gas pressure control flap at a pressure level controlled to $101.3 \mathrm{kPa}$ using a smokemeter (AVL 415s). For the determination of the particle number (PN) within the range from 22 to $523 \mathrm{~nm}$, an engine exhaust particle sampler (EEPS ${ }^{\text {TM }}$ by TSI) was utilised in combination with the rotating disk thermodiluter $379020 \mathrm{~A}$ and 379030 thermal conditioner. The raw exhaust gas was sampled downstream of the back pressure valves, with the connecting line of the exhaust track and diluter head being as short as possible. The diluter head temperature was set to $150^{\circ} \mathrm{C}$. Within the thermal conditioner, the evaporation tubes were heated up to $350^{\circ} \mathrm{C}$.

\section{Experimental results and discussion}

The achievable thermal efficiency of a gasoline engine predominantly depends on the compression ratio, which in turn is limited by the knock resistance of the fuel. For operation with RON95 E5 gasoline, a compression ratio $\left(r_{C}\right)$ of 8.5 was used. The high auto-ignition resistance of ethanol and 2-methylfuran allowed for increasing the compression ratio $\left(\mathrm{r}_{\mathrm{C}}\right)$ to 13.5 . A point of $50 \%$ mass fraction burned (MFB 50) at or close to the optimum of a $7^{\circ}-8^{\circ} \mathrm{CA}$ after top dead centre (ATDC) indicates a high knock resistance and hence the highest possible engine efficiency. Therefore, the spark timing 


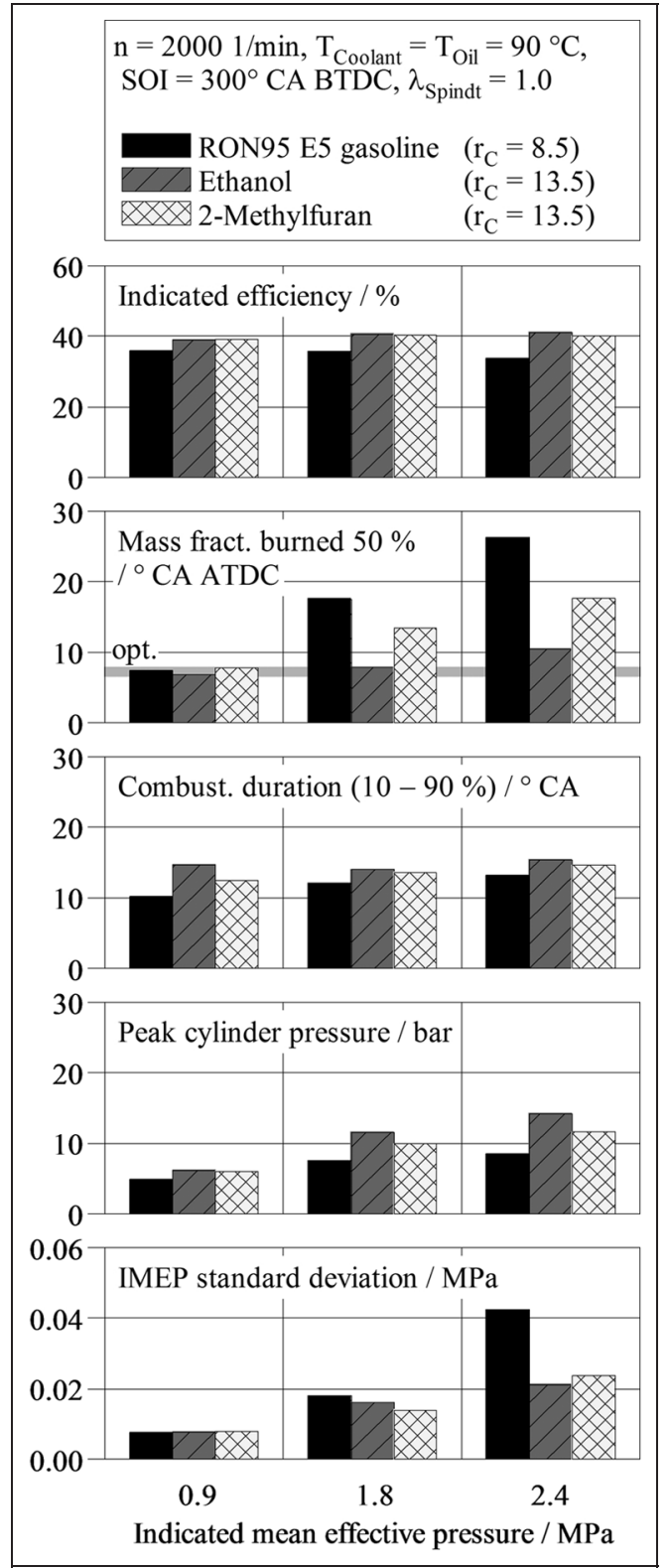

Figure 4. Results of the load variation with the A-nozzle piezo injector.

(ST) was set according to an optimal MFB 50 in case there was no knock restriction for the investigations presented in Figures 4 and 5. The knock resistance in terms of MFB 50 is presented in Figure 4 for 2-methylfuran, as well as for the two reference fuels at an engine speed of $\mathrm{n}=20001 / \mathrm{min}$ at selected load points.

At a load of $0.9 \mathrm{MPa}$ indicated mean effective pressure (IMEP), at which RON95 E5 gasoline is not yet knock-restricted, the efficiency can be increased by $\sim 7.5 \%$ in the case of 2 -methylfuran and $\sim 9 \%$ in the case of ethanol. This efficiency benefit is mainly provided by the increased compression ratio and the better charge cooling, which is due to the higher heat of vaporisation. At a load of 1.8 MPa IMEP, 2-methylfuran is knock-restricted. Thus, a retardation of the combustion becomes necessary. Although a higher compression ratio was chosen, the higher knock resistance of ethanol and

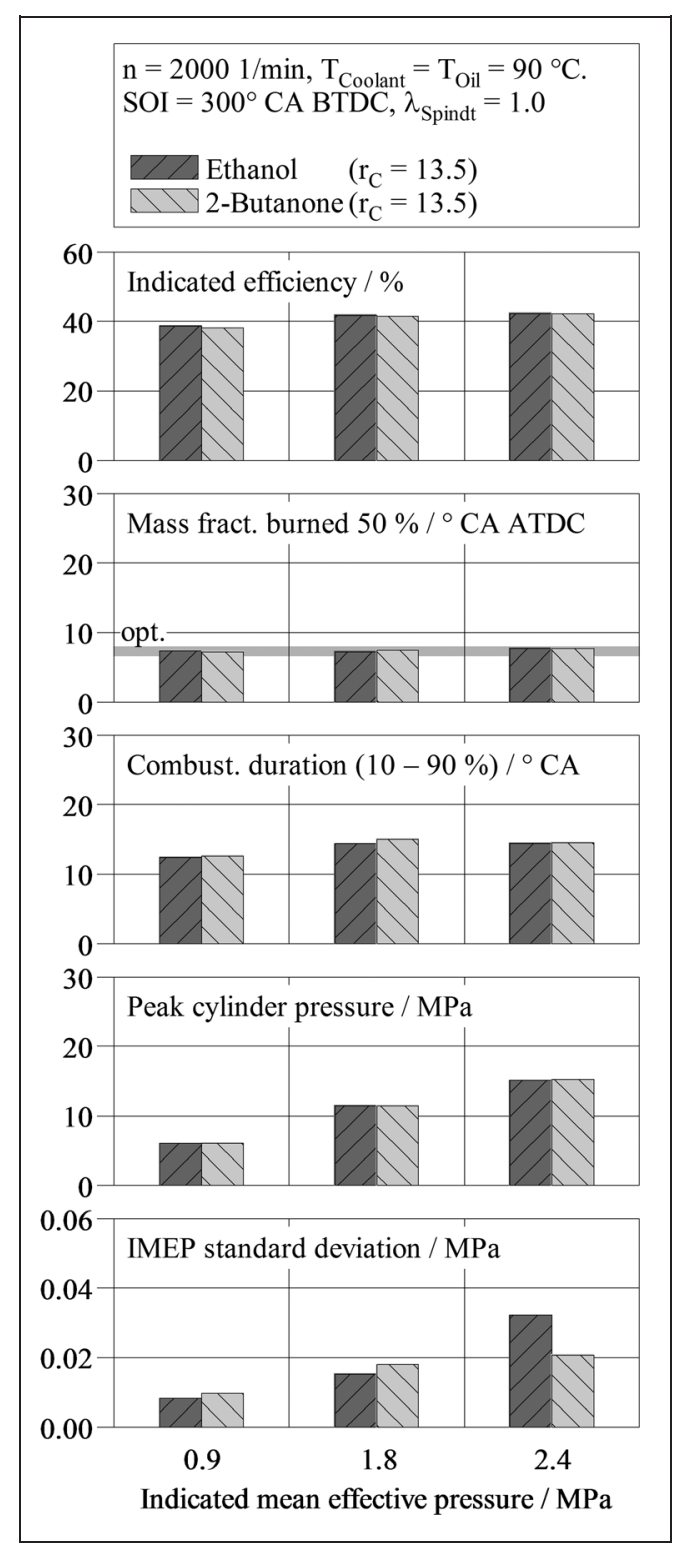

Figure 5. Results of the load variation with the six-hole solenoid injector.

2-methylfuran led to reduced combustion phasing at increased loads. Thus, a further compression ratio increase is possible for ethanol, as well as for 2-methylfuran. An efficiency gain at the highest load point of up to $\sim 18 \%$ for 2 -methylfuran compared to RON95 E5 gasoline was achieved. Ethanol allowed for an efficiency gain of $\sim 21 \%$. The highest average peak pressures were measured for ethanol, as the combustion retardation accompanied the reduced peak pressures. Slightly lower combustion durations were measured for 2-methylfuran compared to ethanol. The lower combustion duration of RON95 E5 gasoline resulted from the different piston geometries due to the different compression ratios compared to ethanol and 2-methylfuran. The strong retardation of the combustion for operation with RON95 E5 gasoline led to a decrease in the combustion stability, indicated by an increase in IMEP standard deviation. However, compared to ethanol, at 2.4 MPa IMEP, only 
a minor increase in the IMEP standard deviation was present due to the rather moderate combustion phasing.

In the next step, the high-load performance of 2butanone was evaluated in comparison to ethanol, which showed the highest knock resistance in prior investigations. The boundary conditions and load points were the same as before. For both fuels, a compression ratio of 13.5 was applied. In contrast to the previously used outward-opening piezo injector, a sixhole solenoid injector was installed. In Figure 5, the results of these investigations are depicted. Due to the optimised spray layout, no knocking could be observed for ethanol - not even at the highest loads. This is contrary to the previous investigations with the outwardopening piezo injector. Similarly, for 2-butanone, no combustion phasing retardation was necessary. The RON of 2-butanone compensated for the lower charge cooling effect. This resulted in nearly identical efficiencies for both fuels. The combination of a high compression ratio and an optimal MFB 50 of $\sim 8^{\circ} \mathrm{CA}$ ATDC enabled efficiencies of up to $42 \%$, even at high loads, allowing for higher compression ratios also in the case of 2-butanone. The slight advantages for ethanol can be explained by lower heat transfer losses due to a cooler cylinder charge. Nearly identical combustion durations and peak cylinder pressures were measured for both fuels, considering the same combustion centre. An advantage for 2-butanone can be seen for the combustion stability at high loads, as the IMEP standard deviation is lower compared to ethanol at an IMEP of $2.4 \mathrm{MPa}$.

In addition to the load sweeps at $20001 /$ min, investigations at the catalyst heating point were conducted to evaluate the mixture formation of different biofuels under difficult boundary conditions. The engine test results of these measurements are shown in Figure 6. For all investigated fuels at this load point, the compression ratio was set to 13.5 and a six-hole solenoid injector was installed. The ST was set to $25^{\circ} \mathrm{CA}$ ATDC. The temperature of the engine fluids was reduced to $40^{\circ} \mathrm{C}$ for engine oil and to $30^{\circ} \mathrm{C}$ for coolant water. The combustion duration was calculated using a 'Three Pressure Analysis' (TPA) in the one-dimensional (1D) simulation tool GT-Power.

In the case of 2-methylfuran, the short combustion duration resulted in good combustion stability, as indicated by the low standard deviation. For ethanol, 2butanone and RON95 E10 gasoline, a nearly equal cyclic variation was measured. The fast combustion of 2methylfuran also led to increased efficiency. For ethanol, a decreased efficiency compared to 2-butanone was measured. This can be explained by higher oil dilution present during operation with ethanol. The fuel insertion into the lubricating oil was calculated from the deviation of the AFR, which is derived from the exhaust gas composition via the Spindt formula ${ }^{25}$ and the AFR determined by the measured mass flows of air and fuel. Most likely, here, the high enthalpy of vaporisation of ethanol led to a deterioration of mixture formation,

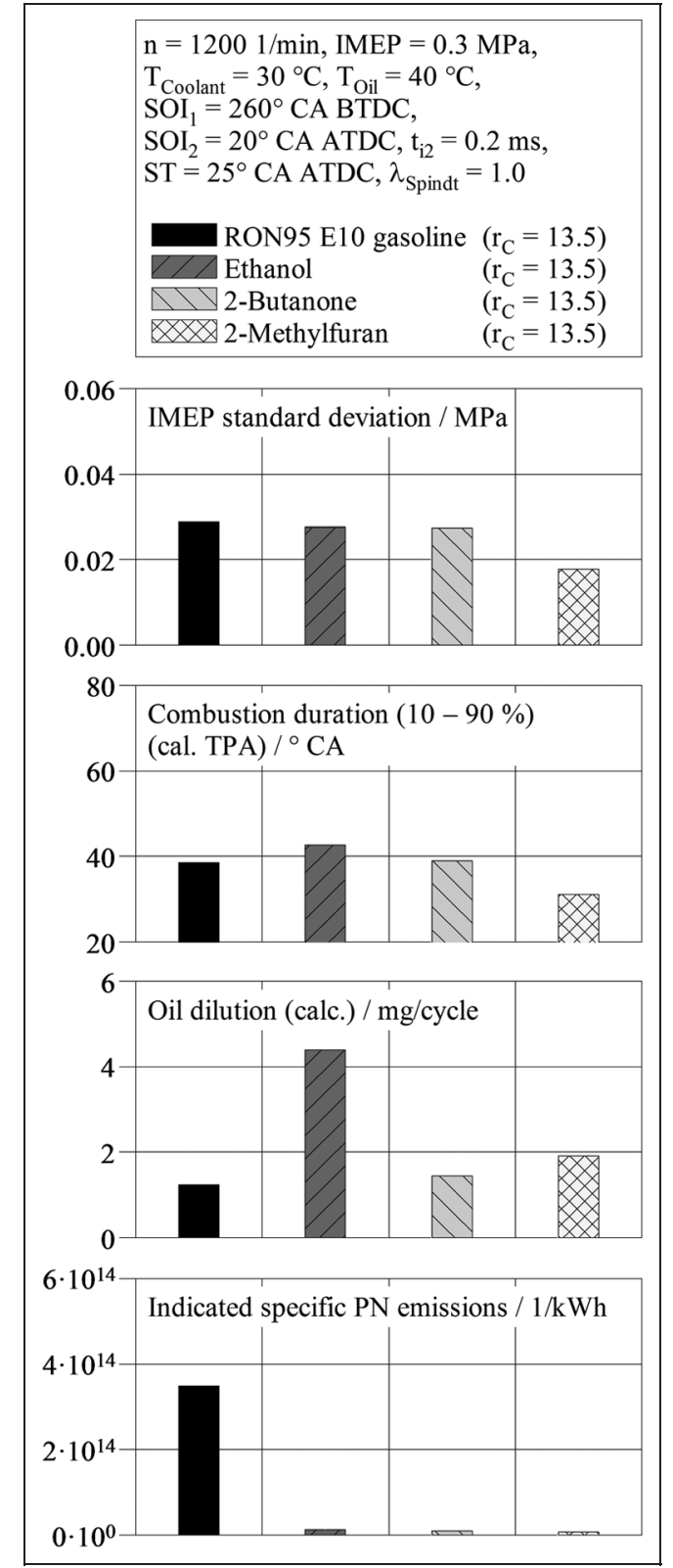

Figure 6. Results of the catalyst heating point with the six-hole solenoid injector.

resulting in increased liner penetration and thus higher oil dilution compared to the other investigated fuels. The low levels of oil dilution in the cases of 2-methylfuran and 2-butanone indicate lower liner penetration and therefore better mixture formation compared to those in the case of ethanol. Strongly reduced particulate matter (PM) emissions compared to RON95 E10 gasoline were present for all three biofuels.

\section{TMFB for clean diesel-type combustion}

Since the start of the CoE, a variety of possible fuel candidates for diesel-type combustion have been identified and investigated. In particular, oxygenated compounds (e.g. furans and alcohols) are favourable in terms of the $\mathrm{PM} / \mathrm{NO}_{\mathrm{X}}$ trade-off, which is often referred to as the 
Table 3. Properties of investigated fuels for $\mathrm{Cl}$ operation. ${ }^{17,18,20}$

\begin{tabular}{llll}
\hline & & Diesel EN590 & I-Octanol \\
\hline Carbon mass fraction & $\%$ & 84.47 & 73.78 \\
Hydrogen mass fraction & $\%$ & 13.27 & 13.93 \\
Oxygen mass fraction & $\%$ & 2.26 & 12.28 \\
Density $\left(20^{\circ} \mathrm{C}\right)$ & $\mathrm{kg} / \mathrm{m}^{3}$ & 820 & 829 \\
Viscosity $\left(25^{\circ} \mathrm{C}\right)$ & $\mathrm{mPa} \mathrm{s}$ & 3 & 7.3 \\
Surface tension $\left(20^{\circ} \mathrm{C}\right)$ & $\mathrm{mN} / \mathrm{m}$ & 20.5 & 27.5 \\
Boiling temperature & $\mathrm{\circ}$ & $170-350$ & 195 \\
Vapour pressure $\left(20^{\circ} \mathrm{C}\right)$ & $\mathrm{kPa}$ & $<0.1$ & 0.0125 \\
Specific enthalpy of vaporisation & $\mathrm{kJ} / \mathrm{kg}$ & 358 & 408 \\
Stoichiometric air requirement & $\mathrm{I}$ & 14.6 & 12.71 \\
Lower heating value & $\mathrm{MJ} / \mathrm{kg}$ & 42.8 & 37.53 \\
Cetane number/derived cetane number* & $\mathrm{I}$ & $5 \mathrm{I}-54$ & $33.1^{*}$ \\
\hline
\end{tabular}

Note: The ' $*$ ' is used to indicate that the cetane number for I-octanol is derived in contrast to the one of diesel.

Table 4. Hardware specifications of the single-cylinder diesel research engine.

\begin{tabular}{llllll}
\hline Bore & $\mathrm{mm}$ & 75 & Bowl diameter & $\mathrm{mm}$ & 48 \\
Stroke & $\mathrm{mm}$ & 88.3 & Bottom bowl diameter & $\mathrm{mm}$ & 36.5 \\
Displacement & $\mathrm{cm}^{3}$ & 390 & Average peak pressure capability & $\mathrm{MPa}$ & 22 \\
Number of valves & $\mathrm{I}$ & 4 & Maximum fuel pressure & $\mathrm{MPa}$ & 220 \\
Maximum absolute boost pressure & $\mathrm{MPa}$ & 0.35 & Fuel pump & Bosch CP4 \\
Integrated swirl number at full valve lift & $\mathrm{I}$ & $\mathrm{I} .18$ & Fuel injector & Bosch CRI 3.20 \\
Compression ratio & $\mathrm{I}$ & $\mathrm{I}$ & Nozzle geometry & 8 -hole, 109 $\mu \mathrm{m}, 153^{\circ}$ \\
\hline
\end{tabular}

'Diesel-dilemma'. 7,26,27 The combination of a high oxygen content of the fuel candidates and low ignitability might cause lower equivalence ratios at the start of combustion and thus lower soot emissions at an equal $\mathrm{NO}_{\mathrm{X}}$ level compared to fossil fuels. Due to the reduced reactivity of 1-octanol in combination with the boiling point at the lower end of the diesel distillation curve and the higher oxygen content of $\sim 12.3 \% \mathrm{~m} / \mathrm{m}, 1$-octanol appears to be a promising candidate for combustion in CI engines. The characteristics that are important for CI operation are summarised in Table 3. In the following, the utilisation of pure 1-octanol, with EN590 diesel fuel as a reference, will be discussed for several engine load points.

\section{Experimental set-up and test conditions}

The single-cylinder diesel research engine (SCE) used for the tests was equipped with fuel injection equipment (FIE) by Bosch that was a near to series production and featured injection pressures up to $220 \mathrm{MPa}$. The layout of the combustion chamber geometry shows a conventional recess shape, which was further optimised together with the nozzle geometry (eight holes) to achieve the best possible air utilisation. The combustion system reached a specific output of $80 \mathrm{~kW} / \mathrm{L}$ at a maximum peak firing pressure of $19 \mathrm{MPa}$. Additional information on the SCE can be found in various publications. $^{28,29}$ Table 4 summarises the main specifications of the engine. Tests were carried out at several partload points, as well as full-load operation. The engine calibration, with regard to boost pressure, injection pressure and centre of combustion (MFB 50), was optimised in previous studies with EN590 diesel (see Table 4). ${ }^{29}$ To ensure comparability between the fuels, all parameters were kept constant with 1-octanol used as fuel as well. However, the start of energising the injector was adjusted depending on the fuel to keep the centre of combustion (MFB 50) constant (Table 5). Engine tests were carried out without any pilot injection. At full load, power was limited by the maximum cylinder pressure, the filter smoke number (FSN) and the exhaust gas temperature. The restrictions are given in Table 6. The set-up of the measurement system differs only in minor details from the one used for the gasoline single cylinder. Therefore, the reader is referred to that section above.

\section{Experimental results and discussion}

In Figure 7, the results of all five part-load points at the EU-6 NO $\mathrm{X}_{\mathrm{X}}$ level for both EN590 diesel and 1-octanol are shown. The upper left graph depicts the smoke emissions. The typical trend of higher PM emissions with increasing load can be observed for diesel. In contrast, PM emissions with 1-octanol can be determined at the highest load point only. At this high engine load, the PM emissions with 1-octanol were reduced by approximately $90 \%$ compared to diesel operation, with both meeting the EU-6 $\mathrm{NO}_{\mathrm{X}}$ level at engine-out. Thus, the higher oxygen content and prolonged ignition delay contributed to a significant reduction in PM emissions and allowed for an almost soot-free diesel combustion.

However, the higher degree of homogenisation is a drawback at low-load operation in terms of increased emissions of hydrocarbons (HC) and carbon monoxide 
Table 5. Engine calibration for all part-load points and engine-out $\mathrm{NO}_{\times}$emissions.

\begin{tabular}{llllllll}
\hline $\begin{array}{l}\text { Engine load } \\
\text { point }(-)\end{array}$ & $\begin{array}{l}\text { Engine speed } \\
\text { and load } \\
(\mathrm{I} / \mathrm{min} / \mathrm{MPa})\end{array}$ & $\begin{array}{l}\text { Centre of } \\
\text { combustion } \\
\left({ }^{\circ} \text { CA ATDC) }\right.\end{array}$ & $\begin{array}{l}\text { Rail } \\
\text { pressure } \\
(\mathrm{MPa})\end{array}$ & $\begin{array}{l}\text { Boost } \\
\text { pressure } \\
(\mathrm{MPa})\end{array}$ & $\begin{array}{l}\text { Charge air } \\
\text { temperature } \\
\left({ }^{\circ} \mathrm{C}\right)\end{array}$ & $\begin{array}{l}\text { Exhaust gas back } \\
\text { pressure }(\mathrm{MPa})\end{array}$ & $\begin{array}{l}\mathrm{EU}-6 \mathrm{NO} \\
\text { level }(\mathrm{g} / \mathrm{kW} \mathrm{h})\end{array}$ \\
\hline $\mathrm{I}$ & $1200 / 0.26$ & 8.0 & 35 & 0.105 & 27 & 0.113 & 0.2 \\
2 & $1500 / 0.43$ & 6.6 & 72 & 0.107 & 25 & 0.113 & 0.2 \\
3 & $1500 / 0.68$ & 5.8 & 90 & 0.15 & 30 & 0.160 & 0.2 \\
4 & $2280 / 0.94$ & 9.2 & 140 & 0.229 & 35 & 0.239 & 0.4 \\
5 & $2400 / 1.48$ & 10.8 & 180 & 0.26 & 45 & 0.280 & 0.6 \\
\hline
\end{tabular}

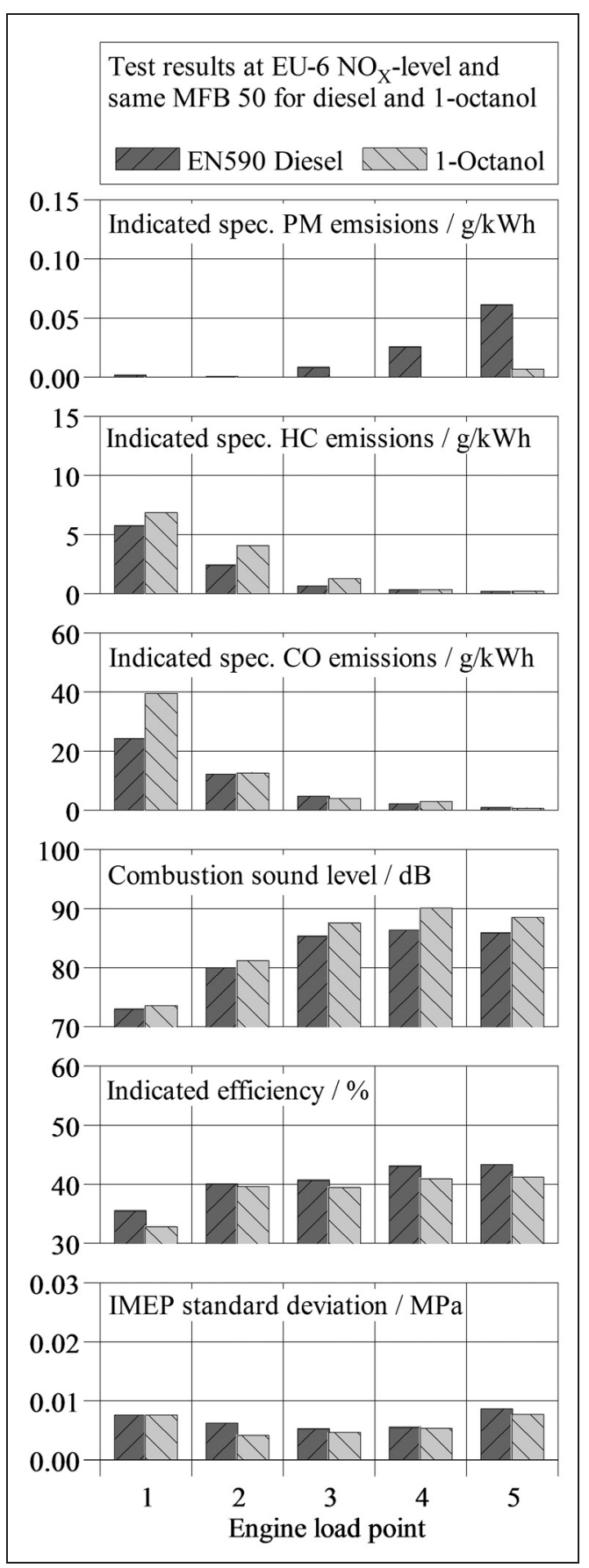

Figure 7. Results at part load with diesel and I-octanol.
(CO). The longer ignition delay caused over-mixing and flame quenching. Because the temperatures were generally low at low loads (LP1-LP3), unburned HCs and $\mathrm{CO}$ could not be post-oxidised, for example, during the exhaust stroke. The combustion sound level (CSL), which is mainly driven by the rate of heat release, was up to $3.5 \mathrm{~dB}$ higher for 1-octanol compared to the reference fuel EN590 diesel. This was also caused by the increased ignition delay because the share of diffusive combustion was reduced in favour of a more premixed combustion. Because the MFB 50 was kept constant for diesel and 1-octanol, the indicated efficiencies were rather similar, as shown in the lower left graph of Figure 7. In LP1, the reduced efficiency with 1octanol might be explained by higher losses due to incomplete combustion, whereas at high loads (LP4 and LP5), the rapid combustion caused higher temperatures and, consequently, higher heat losses. In the lower right graph, the standard deviation in IMEP is given for both fuels. It is notable that even though 1octanol has a DCN of only 33.1, the combustion stability of 1-octanol was comparable to diesel over the entire load range.

The findings at full-load operation are given in Figure 8. As shown by the upper left graph, the IMEP can be increased, in particular at 2000 and $30001 / \mathrm{min}$, with 1-octanol compared to diesel by almost 10\%. At these engine speeds, the FSN (shown in the right graph in the first row) is the limiting factor for IMEP. Obviously, the oxygen atom in 1-octanol either suppresses soot formation to a certain extent or improves post-oxidisation of soot, allowing for higher IMEP at even a lower total AFR (see the lower right graph in Figure 8). Because the ignition delay at these high engine loads was rather similar for both diesel and 1octanol, the soot reduction effect in this load regime could be attributed to the molecular fuel structure and the molecular oxygen content of 1-octanol. At the highest engine speed of $40001 / \mathrm{min}$, the exhaust gas temperature became the limiting factor for both tested fuels, as opposed to the FSN. The increase in load with 1-octanol was not as significant as for 2000 and 3000 $1 /$ min, but at a similar AFR, the reduction in FSN was enormous compared to diesel. 
Table 6. Engine calibration and restrictions at full-load operation.

\begin{tabular}{llllllll}
\hline $\begin{array}{l}\text { Engine speed } \\
(\mathrm{I} / \mathrm{min})\end{array}$ & $\begin{array}{l}\text { Charge air } \\
\text { temperature } \\
\left({ }^{\circ} \mathrm{C}\right)\end{array}$ & $\begin{array}{l}\text { Boost } \\
\text { pressure } \\
(\mathrm{MPa})\end{array}$ & $\begin{array}{l}\text { Exhaust gas } \\
\text { back pressure } \\
(\mathrm{MPa})\end{array}$ & $\begin{array}{l}\text { Rail } \\
\text { pressure } \\
(\mathrm{MPa})\end{array}$ & $\begin{array}{l}\text { Maximum } \\
\text { cylinder pressure } \\
(\mathrm{MPa})\end{array}$ & $\begin{array}{l}\text { Maximum } \\
\mathrm{FSN}(\mathrm{I})\end{array}$ & $\begin{array}{l}\text { Maximum exhaust } \\
\text { gas temperature }\left({ }^{\circ} \mathrm{C}\right)\end{array}$ \\
\hline 1000 & 35 & 0.15 & 1.04 & 100 & 13 & 2.6 & 850 \\
2000 & 46 & 0.245 & 2.46 & 180 & 16 & 1.7 & 850 \\
3000 & 53 & 0.27 & 3.2 & 200 & 19 & 2.5 & 850 \\
4000 & 60 & 0.3 & 3.9 & 200 & 19 & 2.8 & 850 \\
\hline
\end{tabular}

FSN: filter smoke number.

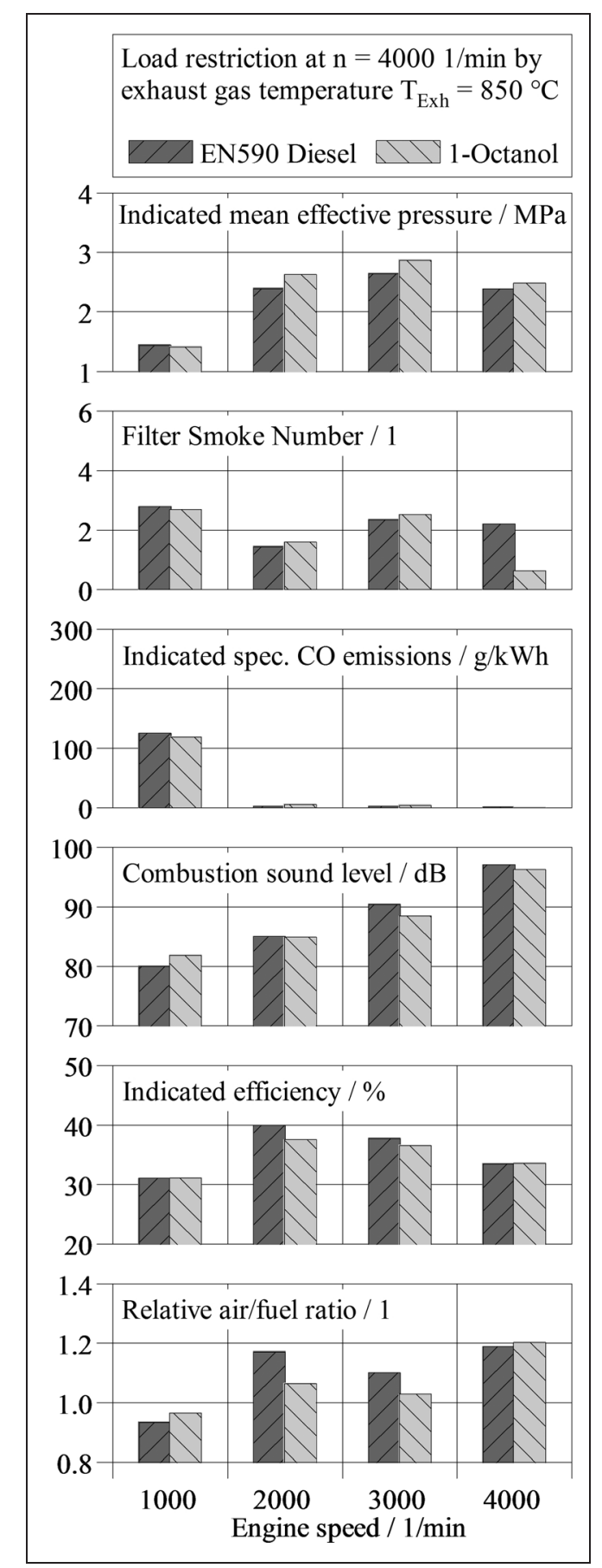

Figure 8. Full-load performance of diesel and I-octanol at different engine speeds.
Due to the under-stoichiometric AFR at $10001 / \mathrm{min}$, $\mathrm{CO}$ emissions were high for both diesel and 1-octanol. However, as a result of the high temperatures, the $\mathrm{HC}$ emissions could be neglected and are not depicted in Figure 8. Contrary to part-load operation, at full-load combustion, noise is typically not the dominant noise source. Because the maximum cylinder pressure was limited and the deviations in ignition delay at high-load conditions were rather small for 1-octanol and diesel, the combustion noise emissions were similar. Considering that the rates of heat release were rather similar, there are no significant differences to be recognised regarding the indicated efficiency. Depending on the engine speed, the difference between diesel and 1octanol was below $2 \%$. This is close to a measurement error.

\section{Conclusion}

Three advanced biofuels have been used to exemplify the opportunities of fuel design, that is, the idea of tailoring the properties of a fuel's molecular structure to the specific needs of future combustion systems.

Engine testing in a SI single-cylinder engine was conducted with both pure 2-methylfuran and 2-butanone, demonstrating considerably lower oil dilution compared to ethanol at the catalyst heat point. Moreover, dramatically lower particle emissions were measured for all biofuels compared to standard gasoline. 2Methylfuran facilitates an improvement in efficiency at full-load operation by $18 \%$ compared to RON95 gasoline. The higher octane rating of 2-butanone allows for an even higher efficiency gain. Conclusively, 2-methylfuran and 2-butanone serve as prototypes of tailormade biofuels, offering superior performance over today's gasoline and bio-ethanol.

For CI engines, 1-octanol shows promising results in terms of the soot $/ \mathrm{NO}_{\mathrm{X}}$ trade-off over almost the entire engine load range. Even at high part load, PM emissions are reduced by $90 \%$ at the EU-6 $\mathrm{NO}_{\mathrm{X}}$ level compared to EN590 diesel fuel. However, at full-load conditions, when approaching an overall equivalence ratio close to 1 , the benefit of the molecular oxygen is not as distinct as at part-load operation. However, at rated power, the PM emissions with 1-octanol are only 
approximately one-third those with the reference EN590 diesel fuel.

\section{Declaration of conflicting interests}

The author(s) declared no potential conflicts of interest with respect to the research, authorship and/or publication of this article.

\section{Funding}

This work was performed as part of the Cluster of Excellence 'Tailor-Made Fuels from Biomass', which is funded by the Excellence Initiative by the German federal and state governments to promote science and research at German universities.

\section{References}

1. International Energy Agency. Energy technology perspectives 2012: pathways to a clean energy system. Paris: International Energy Agency, 2012.

2. Marquardt W, Harwardt A, Hechinger M, Krämer K, Viell $\mathbf{J}$ and Voll A. The biorenewables opportunity toward next generation process and product systems. AIChE J 2010; 56(9): 2228-2235. DOI: 10.1002/ aic. 12380 .

3. Victoria Villeda JJ, Dahmen M, Hechinger M, Voll A and Marquardt W. Towards model-based design of biofuel value chains. Curr Opin Chem Eng 2012; 1(4): 465 471. DOI: 10.1016/j.coche.2012.08.001.

4. Sanders J, Scott E, Weusthuis R and Mooibroek H. Biorefinery as the bio-inspired process to bulk chemicals. Macromol Biosci 2007; 7(2): 105-117. DOI: 10.1002/ mabi.200600223.

5. Marquardt W, Dahmen M, Hechinger M, Recker S, Ulonska K, Viell J and Victoria Villeda JJ. Bioeconomy Science - a chemical engineering perspective. In: 9th World Congress of Chemical Engineering, Seoul, South Korea, 18-23 August 2013.

6. Jäger $\mathrm{G}$ and Büchs J. Biocatalytic conversion of lignocellulose to platform chemicals. Biotechnol J 2012; 7(9): 1122-1136. DOI: 10.1002/biot.201200033.

7. Janssen A, Kremer F, Baron JH, Müther M, Pischinger $\mathrm{S}$ and Klankermayer J. Tailor-made fuels from biomass for homogeneous low-temperature diesel combustion. Energ Fuel 2011; 25(10): 4734-4744. DOI: 10.1021/ ef2010139.

8. Geilen F, Engendahl B, Harwardt A, Marquardt W, Klankermayer $\mathbf{J}$ and Leitner W. Selective and flexible transformation of biomass-derived platform chemicals by a multifunctional catalytic system. Ange Chem: Ger Edit 2010; 122(32): 5642-5646. DOI: 10.1002/ ange. 201002060.

9. Luska KL, Julis J, Stavitski E, Zakharov DN, Adams A and Leitner W. Bifunctional nanoparticle-SILP catalysts (NPs@SILP) for the selective deoxygenation of biomass substrates. Chem Sci 2014; 5(12): 4895-4905. DOI: 10.1039/C4SC02033B.

10. Hechinger M. Model-based identification of promising biofuel candidates for spark-ignited engines. Dissertation, Process Systems Engineering, RWTH Aachen University, Aachen, 2014.
11. Dahmen M, Hechinger M, Villeda JV and Marquardt W. Towards model-based identification of biofuels for compression ignition engines. SAE Int J Fuels Lubr 2012; 5(3): 990-1003. DOI: 10.4271/2012-01-1593.

12. Voll A and Marquardt W. Reaction network flux analysis: optimization-based evaluation of reaction pathways for biorenewables processing. AIChE J 2012; 58(6): 17881801. DOI: 10.1002 /aic. 12704.

13. Thewes M. Potentiale aktueller und zukünftiger Biokraftstoffe für ottomotorische Brennverfahren. Dissertation, Institute for Combustion Engines, RWTH Aachen University, Aachen, 2014.

14. Thewes M, Müther M, Pischinger S, Budde M, Brunn A, Sehr A, et al. Analysis of the impact of 2-methylfuran on mixture formation and combustion in a direct-injection spark-ignition engine. Energ Fuel 2011; 25(12): 5549-5561. DOI: 10.1021/ef201021a.

15. Thewes M, Müther M, Brassat A, Pischinger S and Sehr A. Analysis of the effect of bio-fuels on the combustion in a downsized DI SI engine. SAE Int J Fuels Lubr 2012; 5(1): 274-288. DOI: 10.4271/2011-01-1991.

16. Brassat A, Thewes M, Müther M and Pischinger S. Tailor-made fuels from biomass for gasoline combustion systems. MTZ Worldw 2011; 72(12): 56-63.

17. Yaws CL. Thermophysical properties of chemicals and hydrocarbons. Norwich, NY: William Andrew Inc., 2008.

18. Yaws CL. Transport properties of chemicals and hydrocarbons. Norwich, NY: William Andrew Inc., 2009.

19. Daubert TE and Danner RP. Physical and thermodynamic properties of pure chemicals. New York: Hemisphere Publishing Corporation, 1994.

20. Institut für Arbeitsschutz der Deutschen Gesetzlichen Unfallversicherung (IFA). Gestis-Stoffdatenbank, http:// gestis.itrust.de/nxt/gateway.dll/gestis_de/ 000000.xml?f $=$ templates $\$ \mathrm{fn}=$ default.htm $\$$ vid $=$ gestisdeu:sdbdeu\$3.0 (accessed 29 April 2015).

21. National Institute of Standards and Technology (NIST). NIST Chemistry WebBook, NIST Standard Reference Database Number 69, http://webbook.nist.gov/chemistry/ (accessed 29 April 2015).

22. Bauer K, Heilmann G, Koepcke G, Reders K, Erwig W, Hunwartzen I, et al. Determination of the anti-knock performance (RON and MON) of alcohols and alcohol-gasoline blends in CFR test engines, DGMK Forschungsbericht 260-01, 1980. DGMK: Deutsche Wissenschaftliche Gesellschaft für Erdöl, Erdgas und Kohle e.V.

23. Thewes M, Mauermann P, Pischinger S, Bluhm K and Hollert H. Hydrocarbon raw emission characterization of a direct-injection spark ignition engine operated with alcohol and furan-based bio fuels. In: Proceedings of 9th international colloquium fuels (ed WJ Bartz), Ostfildern, 15-17 January 2013.

24. Heitzig S, Weinebeck A and Murrenhoff H. Testing and prediction of material compatibility of biofuel candidates with elastomeric materials. SAE Int J Fuels Lubr 2015; published 11 January 2015.

25. Spindt RS. Air fuel ratios from exhaust gas analysis. SAE paper 650507, 1965. DOI: 10.4271/650507.

26. Kremer F, Heuser B, Pischinger S and Klankermayer J. Optimizing diesel combustion behavior with tailor-made fuels from biomass. In: Proceedings of 9th international colloquium fuels (ed WJ Bartz), Ostfildern, 15-17 January 2013. 
27. Janssen A, Müther M, Pischinger S, Kolbeck A and Lamping M. Tailor-made fuels: the potential of oxygen content in fuels for advanced diesel combustion systems. SAE paper 2009-01-2765, 2009. DOI: 10.4271/2009-012765.

28. Adolph D, Busch H, Pischinger S, Kolbeck A, Lamping $\mathrm{M}$ and Körfer T. Advanced diesel combustion - a method demonstrating favorable untreated engine emissions with improved consumption characteristics. MTZ Worldw 2008; 69(1): 24-31.

29. Müther M, Lamping M, Kolbeck A, Cracknell R, Rickeard D, Ariztegui $\mathbf{J}$ and Rose K. Advanced combustion for low emissions and high efficiency, part 1: impact of engine hardware on HCCI combustion. SAE paper 200801-2405, 2008. DOI: $10.4271 / 2008-01-2405$.

\section{Appendix I}

Notation

$\mathrm{n}$

$\mathrm{r}_{\mathrm{C}}$ compression ratio

$\mathrm{t}_{\mathrm{i}} \quad$ duration of injection

$\lambda \quad$ relative air/fuel ratio 